\title{
Vitamin C in the Diet of Inuit Hunters From Holman, Northwest Territories
}

\author{
JOSEPH R. GERACI ${ }^{1}$ and THOMAS G. SMITH ${ }^{2}$
}

\begin{abstract}
During the spring and summer months the diet of three Inuit families living in a seal hunting camp south of Holman, N.W.T., was studied. A total of 13 food items including the most commonly eaten mammal, bird and plant species were analysed for Vitamin $\mathrm{C}$ in both the raw and cooked state. We document a daily intake of ascorbic acid of between 11 and $118 \mathrm{mg}$ and estimate a mean does of at least $30 \mathrm{mg}$. This is well above the levels documented in larger transitional culture villages by a recent Nutrition Canada report.
\end{abstract}

RESUME. On a étudié pendant le printemps et l'été, le régime de trois familles Esquimaux qui vivaient dans un camps de chasse au phoque, au sud d'Holman, N.W.T.

Au total, 13 types de nourriture, comprenant les mammifères, le plus souvent mangés, des espèces d'oiseaux et de plantes, etaient analysés pour la recherche de vitamine $C$, soit à l'état crû, soit à l'état cuit. Le resultat est une prise joumalière d'acide scorbique de 11 à $118 \mathrm{mg}$, en moyenne de $30 \mathrm{mgs}$. Ceci est bien au dessus de ce qui a été constaté dans le villages de culture de transition (rapport Canadien sur la nutrition.)

Traduit par Alain de Vendegies, Aquitaine Company of Canada Ltd.

\section{INTRODUCTION}

Early arctic explorers recognized the value of adopting the traditional Inuit diet of raw or boiled fish and meat, with only occasional ground plants and berries (Nansen, 1897). Those who could not or would not endure the change fell victim to malnutrition (Stefansson, 1918). Scurvy, caused by a deficiency of vitamin $C$, was observed in the arctic for the first time among white explorers and trappers who persistently ate "southern" foods. Ironically, the instrusion of southern white culture into northern communities led to the inevitable adoption of processed foods by the Inuit. This, combined with the consolidation of small hunting communities into large villages from which there may be little access to native foods, has gradually resulted in a decline in nutritional status among the Inuit (Draper, 1977).

Subacute scurvy, attributed to the absence of fresh meat, was noted in 28 of 30 Eskimo children examined in Point Barrow, Alaska (Levine, 1940). "Only reindeer killed several months before, was available." A study in 1947 by the Alaska Department of Health, showed that ascorbic acid was consistently lacking in native diets. Of 117 plasma ascorbic acid determinations, 96 were rated poor, 16 fair, and only 5 were within a normal range (Heller, 1949). In a recent study of four major Inuit settlements in the Northwest Territories

\footnotetext{
'Department of Pathology, University of Guelph, Guelph, Ontario

${ }^{2}$ Department of Fisheries and the Environment, Fisheries and Marine Service, Arctic Biological Station, Ste. Anne de Bellevue, P.Q., H9X 3L6
} 
(Eskimo Point, Pelly Bay, Frobisher Bay and Coppermine), a Nutrition Canada survey reported that vitamin $\mathrm{C}$ intake was adequate only in children under five years of age, and clearly low in women over 54 years of age. Between 50 and 80 percent of adults were placed in high risk categories (Anon., 1975a).

Small hunting settlements were necessarily overlooked in the Canada-wide nutritional survey, yet unlike the larger settlements these small communities have retained much of the traditional culture and healthful life style recognized by the early explorers. We undertook this study, as part of a larger investigation into vitamin $\mathrm{C}$ in the arctic food chain, to determine the adequacy of vitamin $\mathrm{C}$ in the summer diet of three Inuit families from Holman, a hunting community of approximately 250 people. Though commercially prepared foods are available and utilized, a large variety of native foods forms the bulk of the diet.

\section{MATERIALS AND METHODS}

Information on the diet of the three Inuit families was gathered by one of us (T.G.S.) while living at Kutuervik, a seal hunting camp 30 miles southeast of Holman, N.W.T., during July-September 1975. Records were maintained on types, frequencies and approximate quantities of foods consumed. Small samples of each raw food item were taken and frozen, usually within 2 hours, in an electric freezer at a field laboratory. The frozen samples were then shipped to Guelph where they were maintained at $-70^{\circ} \mathrm{C}$ for 2 months. They were analyzed, in duplicate, for total ascorbic acid according to the method of Roe and Kuether (1943). Where applicable, sub-samples of each food item were boiled for 10 minutes, then re-analyzed, roughly simulating the simple method of cooking.

\section{RESULTS AND DISCUSSION}

The most common meat item in the hunting camp was caribou. Ringed seal is the most abundant marine mammal, yet it was not consumed to nearly the same extent as the less common but preferred bearded seal or "ugyuk". The flesh of both seal species, caribou and muskox was eaten either fresh-boiled, or dried by draping thinly sliced pieces over rocks or driftwood frames.

Typically, the daily feeding pattern consisted of four meals. The first three were generally of 200-250 g portions of dried meats known as "MIPKO," or of dried arctic char, "BEEFY". These were eaten with tea and bannock, a form of bread with refined flour. The fourth and largest meal of the day was usually a stew, made with flesh, bones, marrow and selected viscera of terrestrial and marine mammals and birds. These were generally eaten in portions of $500-600 \mathrm{~g}$ by adult males, less by the females, and proportionally less by the children. The broth was always consumed as part of the meal. Few plants are available in the vicinity of Kutuervik; they formed an incidental part of the diet. 
TABLE 1. Vitamin C content of raw and boiled food items of the Inuit diet ( $\mathrm{mg} / 100 \mathrm{~g}$ as mean of duplicate determinations on one sample of each food item).

Vitamin $C(\mathrm{mg} / 100 \mathrm{~g})$

Food item Boiled (10 min)

\section{MAMMALS}

Ringed seal (Phoca hispida)

flesh

liver

Bearded seal (Erignathus barbatus)

flesh intestine

Beluga whale (Delphinapterus leucas)

("Muktuk") epidermis

dermis

blubber

Polar bear (Ursus maritimus)

flesh

1

0.8

Muskox (Ovibos moschatus)

flesh (fresh)

flesh (dried)

Caribou (Rangifer tarandus)

flesh

fat

1.4

1.8

0.9

Arctic hare (Lepus arcticus)

1.3

0.8

\section{BIRDS}

Arctic loon (Gavia arctica) flesh

ptarmigan (Lagopus mutus) flesh

King eider (Somateria spectabilis) flesh

FISH

Arctic char (Salvelinus alpinus)

whole fish

flesh (dried)

\begin{tabular}{ll}
5.8 & 0.8 \\
\hline
\end{tabular} 
Table 1 shows the vitamin $\mathrm{C}$ content of the raw and boiled food items eaten during the six-week period beginning 10 July 1975 . Some vitamin degradation may have occurred in the interval between sampling and analysis, thus the values reflect minimum vitamin $\mathrm{C}$ content at the time of eating. Nevertheless, the values are equivalent to or higher than those reported for the same or similar food items by Hфygaard and Rasmussen (1939).

The three minor meals of dried meat or fish, totalling approximately $700 \mathrm{~g}$ for the average adult male, provided at least $7 \mathrm{mg}$ (muskox) to $13 \mathrm{mg}$ (char) of vitamin $C$ per day. The $500 \mathrm{~g}$ main meal of boiled meat provided an additional minimum $1 \mathrm{mg}$ (king eider) to $68 \mathrm{mg}$ (ringed seal liver) of the vitamin. According to Hoygarrd (1941), 35 percent of the vitamin $\mathrm{C}$ leached from boiling bird and seal flesh is recoverable in the stock, which is Kutuervik was always consumed as part of the meal. The broth in this case would have provided an additional 2 to $37 \mathrm{mg}$ of the vitamin.

Certain foods which are not abundant but are eaten when available can augment vitamin $C$ intake. This is particularly true of such items as licorice root, mountain sorrel and "muktuk." Muktuk is undoubtedly the most prized delicacy. It consists of the skin of the beluga whale, with about $2-4 \mathrm{~cm}$ of attached blubber. The thin epidermis contains $38 \mathrm{mg} / 100 \mathrm{~g}$ of vitamin $C$, and is one of the richest sources of the vitamin in the Inuit diet; its antiscorbutic properties were first recognized early in this century (Bertelsen, 1911). During the study period, muktuk was consumed for seven days, at an adult average of $1 \mathrm{~kg} / \mathrm{day}$, thus providing a variably high quantity of vitamin, depending on the proportion of skin and blubber in the serving.

From these figures, we estimate that the adult daily intake of vitamin $\mathrm{C}$ varied between at least 11 and $118 \mathrm{mg}$ during the summer period, with as much as 50 to $100 \mathrm{mg}$ extra when such sources as muktuk were available. Women and children consumed proportionally less of the vitamin. Though vitamin intake was generally sporadic, a conservative estimate would place the mean intake level at or above the $30 \mathrm{mg}$ adult daily allowance established by the Canada Department of National Health and Welfare (Annon., 1975b), and well above the $10 \mathrm{mg}$ minimum dose found to prevent and cure scurvy in

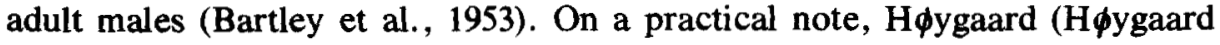
and Rasmussen, 1939) found that only $15 \mathrm{mg}$ of vitamin $\mathrm{C}$ per day was adequate to prevent scurvy on long sledging journeys in the arctic.

The winter diet of the Holman Inuit consists primarily of animal flesh and fat, particularly raw-frozen char and caribou, and stews containing fresh and thawed viscera and meat. This differs from the summer diet principally in that two major meals are consumed rather than one. The winter diet was not analyzed for vitamin $\mathrm{C}$, but extrapolating from our findings on summer foods, eating habits, and the availability of fresh meats, vitamin $\mathrm{C}$ in winter is at least as plentiful as during the summer months. The Holman Inuit seem to enjoy a healthy and robust way of life and it is doubtful that vitamin $\mathrm{C}$ deficiency presents a problem, at least not to the extent reported in the large transitional culture settlements, where native foods are either unavailable or not utilized. 


\section{ACKNOWLEDGEMENTS}

We are grateful for the cooperation of the Inuit of Holman, especially Jimmy Memogana and his family. Mrs. Anne De Freitas provided technical assistance. Drs. H. Draper and E. Evans of the Department of Nutrition, University of Guelph, provided valuable comments on the manuscript.

\section{REFERENCES}

ANONYmous. 1975a. Nutrition Canada: The Eskimo survey Report, Department of National Health and Welfare. Ottawa. $148 \mathrm{p}$.

ANONYMOUS. 1975b. Dietary standard for Canada. Department of National Health and Welfare. Ottawa. $110 \mathrm{p}$.

BERTELSEN. A. 1911. Animalske antiscorbulica i grønland. Hospitalstidende. 54:537-545.

BARTLEY, W. H., KREBS, H. A. and O'BRIEN, J. R. P. 1953. Vitamin C. requirements of human adults. Med. Res. Council Special Report Series, No. 280. 179 p.

DRAPER, H. H. 1977. The aboriginal Eskimo diet in modern perspective. Amer. Anthrop. 79: 309-316.

HELLER, C. A. 1949. The Alaskan Eskimo and the white man's diet. J. Hom. Econ. 41(4): 177-178. HФYGAARD. H. and RASMUSSEN. H. W. 1939. Vitamin C sources in Eskimos' food. Nature, Lond., 143: 943.

H\$YGAARD. A. 1941. Studies on the nutrition and physiopathology of Eskimos undertaken at Angmagssalik, East Greenland, 1926-37. Oslo, Jacob Pybwad, $176 \mathrm{p}$.

LEVINE, V. E. 1940. The ascorbic acid content of the blood of the Eskimo. J. Biol. Chem. 133: xi. NANSEN, F. 1897. Farthest North. Vol. II, N.Y. 671 p.

ROE, J. H. and KUETHER, C. A. 1943. The determination of ascorbic acid in whole blood and urine through the 2, 4-dinitrophenylhydrazine derivative of ascorbic acid. J. Biol. Chem. 147: $399-407$.

STEFANNSON, v. 1918. Observations on three cases of scurvy, 1918. J. Amer. Med. Assoc. 71(21): 1715-1718 